\title{
Dosimetric Evaluation in Radiation Synovectomy
}

\author{
Carla Flávia de Lima and Tarcisio Passos Ribeiro de Campos* \\ Programa de Ciências e Técnicas Nucleares; Universidade Federal de Minas Gerais; Av. Antonio Carlos, 6627; \\ PCA1; campos@nuclear.ufmg.br; Belo Horizonte-MG. - Brasil
}

\begin{abstract}
Rheumatoid arthritis can manifest itself through synovitis, of which the knee is the common locale. The treatment using an intra-articular radioisotope injection has been applied in various countries. In this work, the dose of radioactive material absorbed in the joint is evaluated, taking into consideration the dose received in the articular cartilage and adjacencies using a three-dimensional voxel model representing the knee. The radioisotopes studied were Samarium-153 and Dysprosium-165. The results show that the synovial membrane receives 85 to $98 \%$ of the normalized dose taken from all voxels representative of the synovium. The following features of ${ }^{153} \mathrm{Sm}$ and of ${ }^{165} \mathrm{Dy}-$ its short physical half-life, the gamma emissions with low energy which allow monitoring the injection trough scintigraphy images, the possibility of binding themselves to macroaggregates that are retained in the joint, the high percentage of the effective dose spread in the synovial membrane-make these suitable radioisotopes for radiation synovectomy.
\end{abstract}

Key Words: Rheumatoid arthritis, radiation synovectomy, dose absorbed

\section{INTRODUCTION}

Rheumatoid arthritis (RA), a systemic disease of the connective tissue, whose alterations occur in the areas of articular, periarticular and tendinous structures, manifests itself through local inflammation. The major occurrence is in the synovial membrane. Almost half of the patients diagnosed with RA have problems with the knee joint (Vidigal, E., Jacoby, R.K., Dixon, A., St. J., Ratliff, A. H and Kirkup, J., 1975).

The first consideration to be made in the treatment of the RA is to determine the disease level and the degree of functional loss. Often, the first treatment used is the prescription of anti-inflammatory drugs, steroids and others. (Chinol, M., Vallabhajosula, S. and Goldsmith, S. J., 1991) In some cases, this treatment may not be effective, and may cause the formation of pannus and the destruction of the articular cartilage, requiring surgical treatment, arthrodesis, or placing a total prothesis of the knee. Surgical synovectomy is expensive and requires the patient to be hospitalized several days. The surgery may have side effects such as the possibility of a local infection and loss of joint mobility. Arthroscopic synovectomy of the knee may be less invasive, but the results are limited (Ferkel, 1991). When conventional treatment fails or surgery is impossible, radiation synovectomy (RS) may be applied. This technique consists of an intraarticular injection of colloids or macroaggregates bound to radionuclide (RN's) beta-emitters. The objective is to destroy the diseased pannus and inflamed synovium by direct and highly selective irradiation, with the expectation that following synovium destruction, the regenerated synovium will be free of disease. It's necessary that the

* Author for correspondence 
colloidal particle be large enough to remain intraarticular for at least a half-life of the RN and avoid irradiation of remote organs.

RS was first proposed in 1952 by Fellinger and Schmit and described by Ansell et al. (1963). An intra-articular injection of colloidal ${ }^{198} \mathrm{Au}$ was used in the treatment of RA. However, the gold-198 used in the treatment had its inconveniences, such as gamma emission of high energy and particle sizes that resulted in excessive loss of colloid to lymphatic system and, consequently, the absorption of high doses of radiation by the liver and linfonodes. After the 1960's, with the production of beta-emitter radioisotopes with short half-lives, lower gamma emission, and having the ability to bind themselves to macroaggregates, new possibilities appeared for RS (Ingrand, 1973). Today, this treatment is applied extensively and routinely in Europe. The RN's are available to RS, for the most part, having a short physical half-life and emitting ionizing particles with an average affective tissue penetration (The maximum penetration is less than $10 \mathrm{~mm}$ ). The objective is to reach the inflamed synovia, producing an absorbed dose sufficient to eliminate the disease. Another desirable feature is the existence of a combined emission of low-energy gamma rays that can generate a scintigraphy image to evaluate the quality of the injection and to monitor the migration of RN in the lymphatic system. It is important that the radioisotope be available, nontoxic and chemically pure (Murray, J.P., Ell, P.J, 1998).

Thus, dysprosium-165 ( ${ }^{165} \mathrm{Dy}$ ) and samarium-153 $\left({ }^{153} \mathrm{Sm}\right)$ present features suitable for use in RS treatment. These RNs have a short physical halflife, emit beta and gamma rays of low energy, and can bind themselves to macroaggregates (particles of an adequate size) so that there is no radioactive spreading in the lymphatic system. Their use is expected to reduce inflammation and pain and improve the articular mobility (Esteban, C.C., Wilke, W.S, 1995).

The activity of RN's to be administered in RS is not standardized. The RN should have an average effective tissue penetration, close to the thickness of the inflamed synovium. The absorbed dose should be sufficient to eliminate the disease. Thus, dosimetry has a important role in the RS. (Johson, L.S., Yanch, 1993; Yoriyaz, H., Stabin, M.G., Santos, A.D., 2000).

The objective of this work was to evaluate the deposition of energy in various components of the joint and adjacent tissues using the knee as a model. RS will be simulated based on ${ }^{165}$ Dy and ${ }^{153} \mathrm{Sm}$ radionuclide sources. Based on this model, the radionuclide selection and the specific activity prescribed can be predicted, avoiding the risks of sub- or super-exposure to the adjacent tissues.

\section{MATERIALS AND METHODS}

A model of the synovium was created. The simulation applied the stochastic Monte Carlo nuclear code (Metropolis, N., 1987). A number of $30 \times 30 \times 16$ voxels reproduced the transversal sections of the human knee. Each section was obtained from a magnetic nuclear resonance image (MRI). A three-dimensional model representative of the morphology and anatomy of the knee was prepared. The voxel model contained interposed volumes represented by an analytic geometry that composed the superior and inferior part of the knee. In the model each voxel of $0.5 \times 0.5 \times 0.4 \mathrm{~cm}^{3}$ was filled with material similar to the human tissue: bone, cartilage, synovial liquid, muscle and adipose tissue, according to its appearance in the tomography and according to the anatomy described in the literature. (Dângelo, J., Fattini, C., 1998 and Sobotta, J., 1990).

The RNs were homogeneously distributed in the synovial liquid. The absorbed doses generated by photons and electrons were evaluated using the Monte Carlo Code (MCNP5). The distribution of the continuous emission of electrons (beta decay) and the discrete distribution of gamma rays, $\mathrm{X}$ rays and Auger electrons were assumed for each RN ${ }^{165} \mathrm{Dy}$ and ${ }^{153} \mathrm{Sm}$, whose characteristics are described in Table 1.

For each RN, the spatial distribution of the percentage and normalized dose from 0 to $100 \%$, as a function of the maximum dose percentage, was evaluated. The comparison of the absorbed dose in the synovium for the two RNs was made, establishing a fixed dose of $37 \mathrm{MBq}(1 \mathrm{mCi}=3.7$ $x 10^{7} \mathrm{~Bq}$ ) and considering the volume of the defined voxel $0.5 \times 0.5 \times 0.4 \mathrm{~cm}^{3}$ and a mass of $0.1 \mathrm{~g}$. Table 2 shows the energetic distribution function of the emitted beta particles. The distribution of the gamma rays, $\mathrm{X}$ rays, and Auger electrons are not shown in Table 2. Nevertheless, they were used in simulations. 


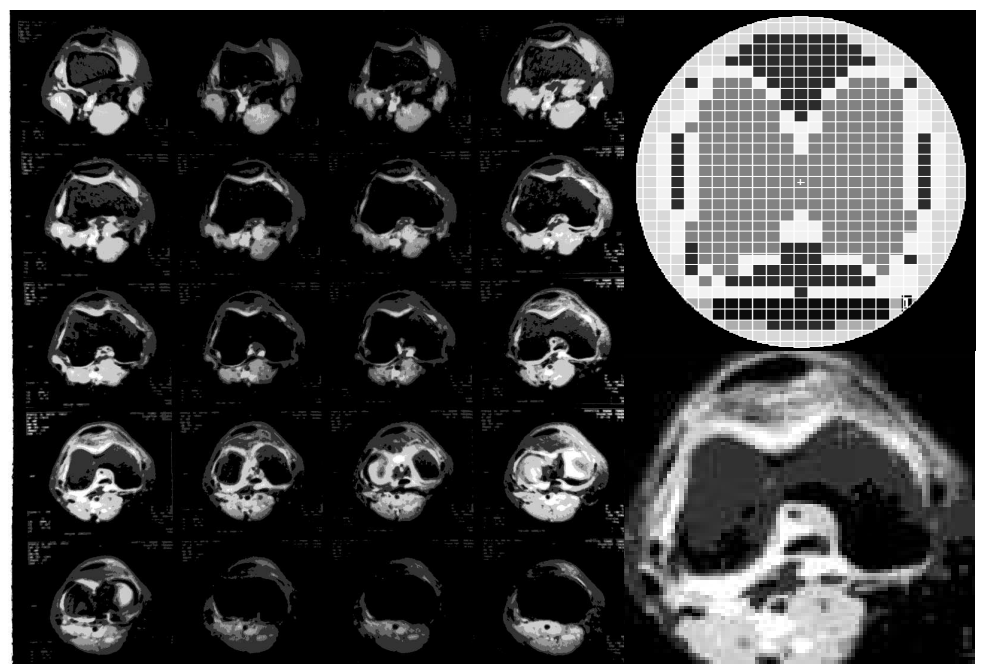

Figure 1 - MRI Tomography, digitalized, and represented in voxels composing the threedimensional voxels model. A central transversal section of the model and the images associated, in which the gray scale represents distinct tissues, is shown

Table 1. Characteristics of the radioisotopes simulated in this work (Shackett, P., 1999)

\begin{tabular}{ccccc}
\hline Isotope & $\begin{array}{c}\text { Physical half-life } \\
\text { (days) }\end{array}$ & $\begin{array}{c}\text { Beta maximum energy } \\
(\mathbf{M e V})\end{array}$ & $\begin{array}{c}\text { Soft tissue penetration } \\
(\mathbf{m m})\end{array}$ & $\begin{array}{c}\text { Gamma energy } \\
(\mathbf{k e V})\end{array}$ \\
\hline $\begin{array}{c}\text { Disprósio- 165 (Dy- } \\
\text { 165) }\end{array}$ & 0.1 & $1.29(83 \%)$ & 5.7 & $95(4 \%)$ \\
& & $1.19(15 \%)$ & & $103(28 \%)$ \\
Samário-153 (Sm- & 1.9 & $0.634(34 \%)$ & 2.5 & \\
$153)$ & & $0.702(44 \%)$ & & \\
& & $0.805(21 \%)$ & & \\
\end{tabular}

Table 2 - Function of energetic distribution of the beta particles emitted.

\begin{tabular}{|c|c|c|c|c|c|}
\hline \multicolumn{2}{|c|}{${ }_{66} \mathrm{Dy}^{165}$} & \multicolumn{4}{|c|}{${ }_{62} \mathrm{Sm}^{153}$} \\
\hline$\Delta \%$ & $\Delta \mathrm{E}$ & \multicolumn{3}{|c|}{$\Delta \%$} & \multirow[t]{2}{*}{$\Delta \mathrm{E}$} \\
\hline 0.36 & $0.00-0.25$ & B 1 & B 2 & B 3 & \\
\hline 0.34 & $0.25-0.50$ & 0.38 & 0.43 & 0.33 & $0.0-0.1$ \\
\hline 0.22 & $0.50-0.75$ & 0.25 & 0.27 & 0.23 & $0.1-0.3$ \\
\hline 0.08 & $0.75-1.00$ & 0.17 & 0.17 & 0.17 & $0.3-0.4$ \\
\hline \multirow[t]{5}{*}{0.0} & $1.00-1.28$ & 0.10 & 0.09 & 0.12 & $0.4-0.5$ \\
\hline & & 0.06 & 0.04 & 0.08 & $0.5-0.6$ \\
\hline & & 0.035 & 0.003 & 0.04 & $0.6-0.7$ \\
\hline & & 0.005 & - & 0.03 & $0.7-0.8$ \\
\hline & & - & - & 0.0001 & $0.8-1.0$ \\
\hline
\end{tabular}

\section{RESULTS}

The absorbed energy per unit voxel mass per RN transition, occurring in an arbitrary voxel that absorbed the maximum energy from particle emission is shown in Table 3. The values of the absorbed doses are $100 \%$ of the maximum dose. The results are discriminated by the disintegration 
of each beta and gamma emission. The data was evaluated multiplying the Gy/transformation by the prescribed activity of $3.7 \times 10^{7} \mathrm{~Bq}$ and by the yield of the emission. The absorbed energies from the beta particles were divided by the mass of 0.1 $\mathrm{g}$, which is the mass of the arbitrary voxel. The absorbed energy, in $\mathrm{MeV} \cdot \mathrm{g}^{-1} /$ transition, was transformed by the conversion factor $1.6 \times 10^{-8}$ cGy $\times(\mathrm{MeV} / \mathrm{g})^{-1}$. The maximum absorbed dose imparted, in cGy per $37 \mathrm{MBq}$ (or $\mathrm{mCi}$ ), was evaluated by multiplying the percentage of the maximum dose rate (Tdmax.) by the physical halflife in seconds and by $1.44(\ln 2)$.

The distribution of the dose in the knee -0 to $100 \%$ - obtained from a transversal section at the $\mathrm{Z}=0$ position, generated from the beta disintegration and the emission of photons from the RN is exemplified in Tables 4 and 5.

Table 3 - Maximum specific energy per transition evaluated by MCNP5.

\begin{tabular}{ccccc}
\hline Radionuclide & $\begin{array}{c}\text { Absorbed energy } \\
\text { Electron }(\mathbf{M e V}) \\
\text { Photon(MeV/g) }\end{array}$ & $\begin{array}{c}\text { \% } \\
\text { emission/transformati } \\
\text { on }\end{array}$ & $\begin{array}{c}\text { Dose rate } \\
(\mathbf{c G y} / \mathbf{s}) / 37 \mathbf{M B q}(\mathbf{m C i})\end{array}$ & $\begin{array}{c}\text { Maximum imparted } \\
\text { dose } \\
(\mathbf{c G y} / \mathbf{m C i})\end{array}$ \\
\hline $\begin{array}{c}\text { Disprósio-165 } \\
\text { (photons) }\end{array}$ & $3.986 \mathrm{e}-06$ & n.s. & $23.62 \mathrm{e}-07$ & $2.8570 \mathrm{e}-02$ \\
Disprósio-165 (beta) & $4.404 \mathrm{e}-04$ & 0.83 & $21.66 \mathrm{e}-04$ & $2.6199 \mathrm{e}+01$ \\
Samário-153 (beta1) & $4.396 \mathrm{e}-04$ & 0.44 & $11.46 \mathrm{e}-04$ & $2.7743 \mathrm{e}+02$ \\
$\quad$ Samário-153 & $4.391 \mathrm{e}-04$ & 0.34 & $8.84 \mathrm{e}-04$ & $2.1401 \mathrm{e}+02$ \\
$\quad$ (beta 2) & $4.393 \mathrm{e}-04$ & 0.21 & $5.46 \mathrm{e}-04$ & $1.3218 \mathrm{e}+02$ \\
$\quad \begin{array}{l}\text { Samário-153 } \\
\text { (beta 3) }\end{array}$ & & & & $1.7575 \mathrm{e}+01$ \\
\hline
\end{tabular}

w.s. - without significant

Table 4 - Percentage of dose by electron emission from Disprosium-165 in which Dmax = 21.66e-04 cGys/37 MBq (or $\mathrm{mCi}$ ), obtained by Monte Carlo Code MCNP, with errors lower than 5\%. The non-filled spaces represent values lower than $1 \%$.

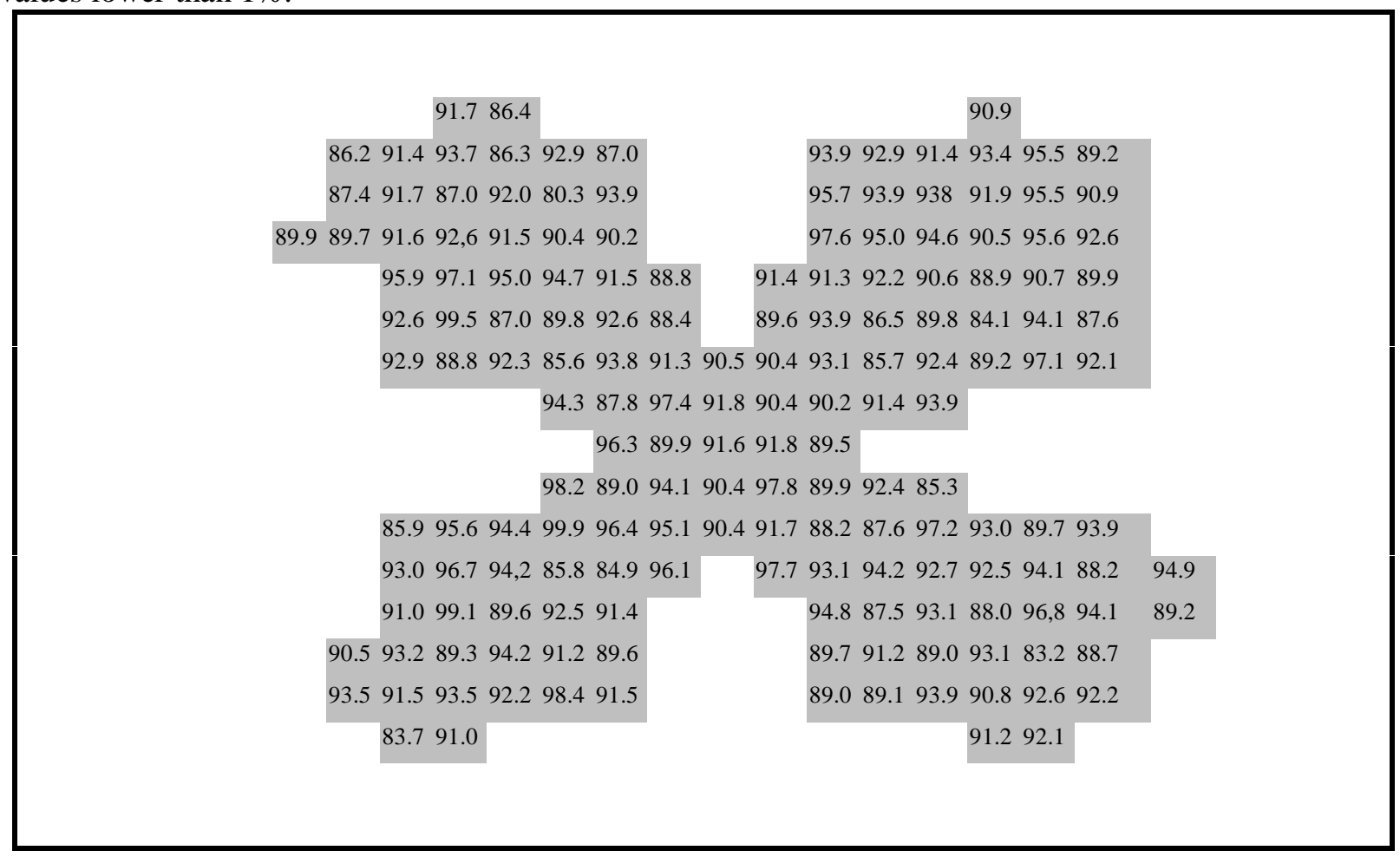


Table 5 - Dose percentage by electron emission of Disprosium-165 in which Dmax = 23.62e-07 cGys/37MBq (or $\mathrm{mCi}$ ), obtained by Monte Carlo Code MCNP, with errors lower than 5\%. The non-filled spaces represent values lower than $1 \%$.

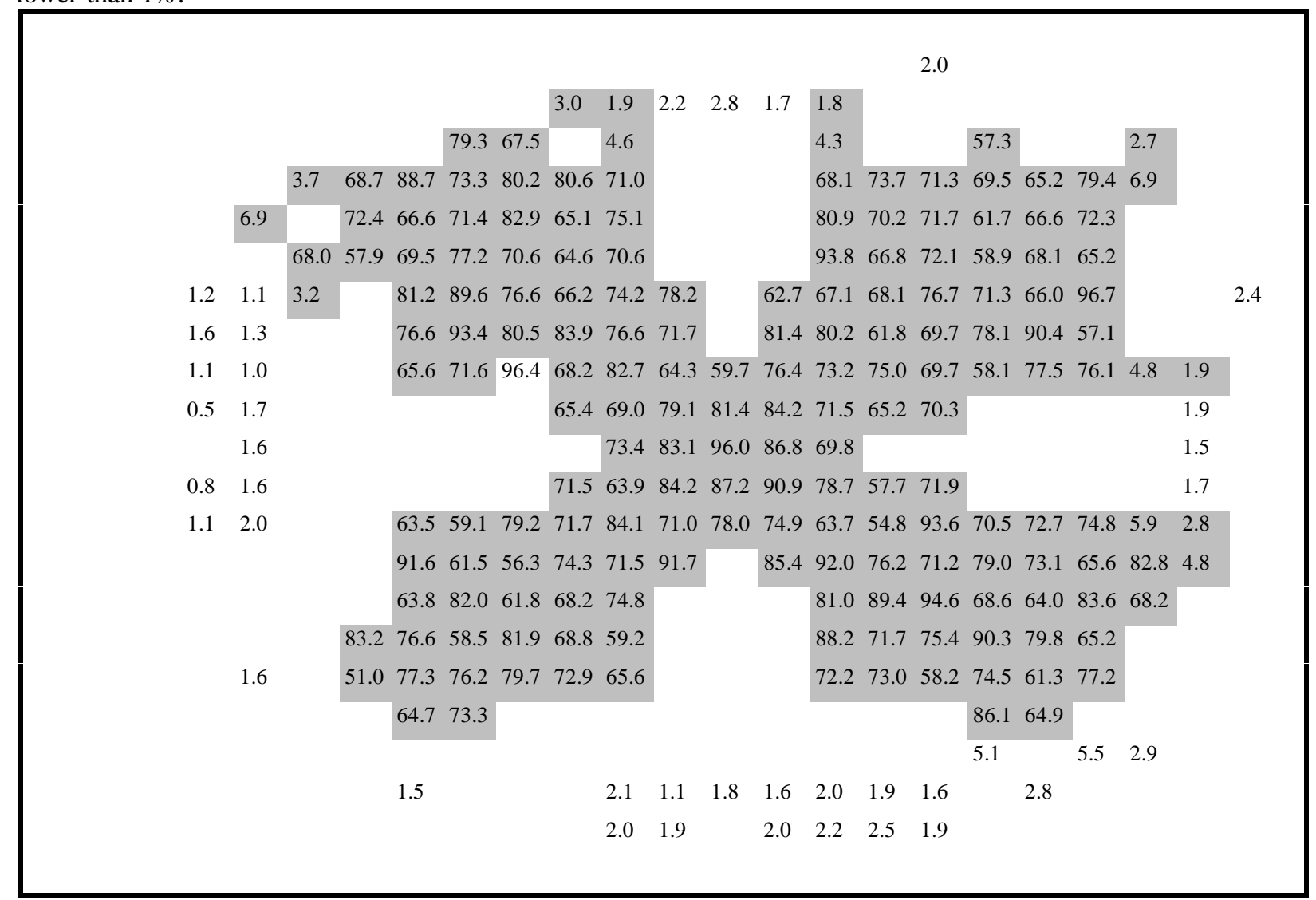

As shown in Table 4 and 5 , the voxels that represent the synovial membrane received a percentage of the maximum dose varying from 58 to $98 \%$ of the maximum dose in all beta emission cases. This value reached 40 to $80 \%$ of the maximum dose of gamma emission. A value close to $95 \%$ of the maximum dose was obtained in the synovial liquid in all cases.

The spatial distribution of the dose due to gamma emission is distinct from that of beta emission; nevertheless, it contributes very little to the total percentage of the dose in the knee structure. An important parameter that particularly contributes to the imparted absorbed dose is the physical half-life of the radioisotope.

It was also verified that the absorbed dose from beta emission per injected activity (37 MBq) fell quickly with the penetration range in the synovial membrane. This fall was particularly influenced by the beta spectrum of the RN in question.

\section{DISCUSSION}

The results of this work were similar to those published in the literature, which has cited percentages of normalized doses varying from $100 \%$ in synovial liquid for different RNs. (Sledge, C.B., Noble, J., Hnatowich, D.J., Kram, R., Shortkroff, S, 1997 and Yoriyaz, H., Stabin, M.G., Santos, A.D., 2000 and Shortkroff, S., Mahmood, A., Sledge, C.B., Jones, A.G, 1992). However, the use of ${ }^{153} \mathrm{Sm}$ and ${ }^{165}$ Dy has not been tested previously, and such a test is justified because of their short physical half-lives (1.9 and 0.1 days, respectively). The emission of beta and gamma rays with relatively low energy and adequate tissue penetration, in addition to the RN's commercial availability, relatively low cost and the possibility of binding to colloids of suitable size, avoiding extra joint leakage, make these RNs adequate choices for carrying out RS. 


\section{RESUMO}

A artrite reumatóide pode se manifestar usualmente pela inflamação da membrana sinovial caracterizada como sinovite, sendo o joelho um substrato comum. O tratamento com a injeção intra-articular de radioisótopo, ou sinovectomia radioisotópica, vem sendo estudado. Neste trabalho será calculada a dose absorvida na sinóvia e nas adjacências através de um modelo tridimensional de voxels. Os radioisótopos estudados foram o Samário-153 e o Disprósio-165. Os resultados obtidos mostraram que uma taxa de dose máxima normalizada variando de 85 a $98 \%$ da dose máxima foi atingida em todos os voxels representativos da membrana sinovial. As características nucleares do Samário-153 e do Disprósio-165, associadas à taxa de dose efetiva recebida na articulação, fazem destes radioisótopos uma escolha na sinovectomia radioisotópica.

\section{REFERENCES}

Ansell, B.M., Crook, A., Mallard, J.R. and Bywaters, E.G.L.(1963), Evaluation of intra-articular colloidal gold ${ }^{198} \mathrm{Au}$ in the treatment of knee effusions. Ann Rheum. Dis., 22, 435-439.

Chinol, M., Vallabhajosula, S. and Goldsmith, S. J.(1991), Evaluation of new radiopharmaceuticals for radiation synovectomy. The Journal of Nuclear Medicine, 32, 963.

Dângelo, J., Fattini, C. (1998) Membro inferior. InAnatomia Humana Sistêmica e Segmentar. Livraria Atheneu, Rio de Janeiro, pp. 177-263.

Esteban, C.C., Wilke, W.S. (1995), Innovative treatment approaches for rheumatoid arthritis. Baillieres Clin. Rheumatol., 9 (4), 787-801.
Ferkel, R.D.(1991), Soft tissue pathology of the ankle. In-Operative Arthroscopy. McGinty el al, New York, p. 713 .

Ingrand, J.(1973), Characteristics of radioisotopes for intra-articular therapy. Ann. Rheum. Dis., supl. 3, 3238.

Johson, L.S., Yanch, J.(1993), Calculation of beta dosimetry in radiation synovectomy using Monte Carlo simulation. Med. Phys., 20 (3), 747-754.

Metropolis, N.(1987), The beginning of the Monte Carlo method. Los Alamos Science: Special Issue, 125-130.

Murray, J.P., Ell, P.J.(1998), Radioisotope synovectomy. In-Nuclear Medicine in Clinical Diagnosis. Churchill Livingstone, Edinburg, pp. 1293, 1998.

Shackett, P.(1999), Radioactive Isotopes. In-Nuclear Medicine Tecnology: Procedures and Quick References. Lippincott Williams and Wilkins, Baltimore, MD, pp. 362,375.

Shortkroff, S., Mahmood, A., Sledge, C.B., Jones, A.G. (1992) Studies on Ho-166-labeled hidroxiapatite: A new agente for radiation synovectomy. Journal of Nuclear Medicine. 33 (5) (Abstract), 937.

Sledge, C.B., Noble, J., Hnatowich, D.J., Kram, R., Shortkroff, S. (1997), Experimental radiation synovectomy by ${ }^{165}$ Dy Ferric hydroxide macroaggregate. Art. and Rheum., 20 (7), 1334:1342.

Sobotta, J. (1990) Cíngulo pélvico e membro inferior. In-Atlas de Anatomia Humana vol. 2, Guanabara Koogan, Rio de Janeiro, p. 262.

Vidigal, E., Jacoby, R.K., Dixon, A., St. J., Ratliff, A.H., and Kirkup, J.(1975) The foot in chronic rheumatoid arthritis. Ann. Rheum. Dis., 34, 292.

Yoriyaz, H., Stabin, M.G., Santos, A.D.(2000), Monte Carlo, MCNP-4B based dose distribution estimates for patient especific dosmetry. Journal of Nuc. Med. 42 (4), 662-669.
Received: June 29, 2005; Revised: July 14, 2005; Accepted: August 01, 2005. 